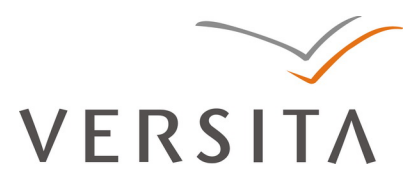

DOI: 10.2478/genst-2013-0017

\title{
WOMEN WHO HAVE FEAR OF UNCLE SILAS: A STYLISTIC APPROACH
}

\section{ELENA MARIA EMANDI}

The "Ştefan cel Mare" University of Suceava, Romania

13 Universității Street, 720229, Suceava, Romania

maria_emandi@yahoo.com

\begin{abstract}
The present paper attempts to categorize the different types of feminine characters who interact in one way or another with Silas Ruthyn. Emphasis will be placed upon the stylistic marks that appear in the Sheridan Le Fanu novel in which the mauvais sujet is dealt with.
\end{abstract}

Keywords: fear, literary stylistics, Uncle Silas, women

\section{Introduction}

Perhaps the first true Victorian neo-Gothic novel, Uncle Silas was written by the Anglo-Irish writer Joseph Sheridan LeFanu, a member of the same Anglo-Irish ascendancy that produced many other impressive personalities. The novel has a very traditional plot and was praised above all for its air of tension. 
Beautiful Maud belongs to a heroine-prototype that appears in a very large number of works. The heiress promises her exacting and aristocratic father that she will restore the family's honour. She is entangled in an odd relationship with her uncle, a relationship that can be termed magnetic to "everything strangest and most powerful" (Bowen 1950:3) in Le Fanu's imagination and temperament. According to Elizabeth Bowen, "Accretion is a major factor in art. Le Fanu could not be rid of the niece and uncle till he had built around them a comprehensive book." (Bowen 1950:3) In fact, Uncle Silas appears in the novel at quite a late point. The author first chooses only to hint at him. Then the reader is presented with a portrait of him painted when he was young - a portrait that was to create a deep impression upon his naïve young niece - and only later does Maud meet him in person. Le Fanu uses this strategy in order to create tension and enrich the atmosphere required in the adventures of a Gothic heroine.

As is usual in Le Fanu, the victimized protagonists are female. The writer uses Ann Radcliffe's Gothic frame, which favours the "feminine romance" in which a girl is carried away from home by force. Nevertheless, Le Fanu departs from Radcliffe's typology by choosing to place the villain in the family. This time the danger comes from within the family, and thus Le Fanu "renders the gates that are supposed to protect the female victim from the outside ineffectual, as he enters them willingly, and finds danger within." (Ogawa 2007:19)

\section{Women Characters in Uncle Silas}


The characters in Uncle Silas, the story of a Gothic heroine whose life is in danger, may be categorized as either life-dealing or death-dealing, depending on whose side they are on. The feminine characters revolve around either Maud or Silas - they are the two polarizing centres - and it is in connection with their interests that they play a part in the economy of the novel. Maud's satellites are Cousin Monica and, later in the novel, the gypsy enchantress, Milly, and Meg Hawkes. The only feminine character linked with Silas is Madame de la Rougierre. There are also two other less important characters - two servants: Mary Quince, Maud's companion, and Old Wyat (or Old L'Amour as Milly nicknames her), Silas's faithful servant. The only feminine character who gains a mention in the novel but who has no connection with Maud's fate is Silas's dead wife. The explanation of her presence in the novel is to be found in Le Fanu's interest in being accepted and read by an English audience. Silas's lowclass wife is a presence designed to please the English reader. Monica Knollys represents her to Maud as having been coarse and vulgar: "not a bit unworldly, but very vicious [...] She was very beautiful, curiously beautiful, for a person of her station [...] - elegantly beautiful, but perfectly low and stupid" (Le Fanu 1864:148). Le Fanu chose to undermine his own Irish peerage in some passages in the novel. He even opted for a setting in England. Nevertheless, he developed the text's directly and structurally Irish features through "its emphasis on sexual corruption and its preoccupation with Maud's femininity" (Howes 1992:168).

Uncertainty in Anglo-Irish discourses was connected with representations of gender and sexuality. Given the circumstances of the Irish having to be assimilated to the English model of good citizens and of the 
imperial discourses that characterized such assimilation as a progress from barbarism to civilization, it was normal for specters to haunt the colonial and especially the Anglo-Irish imagination. Colonial discourses were used to allegorize Anglo-Irish relations in a family romance and expressed "fear of such a romance between Saxon and Celt on a literal level" (Howes 1992:170). This contemporary assimilationist trend was marked by some central ambivalences that appear more evidently in Anglo-Irish literature, as demonstrated by Matthew Arnold's On the Study of Celtic Literature. Arnold connects the Celts to femininity, marked by nervousness, inconsistency, and lack of balance:

no doubt the sensibility of the Celtic nature, its nervous exaltation, have something feminine in them, and the Celt is thus peculiarly disposed to feel the spell of the feminine 'idiosyncrasy' he has an affinity to [quoted in Howes 1992:347]

As contemporary theories on the racial differences between Saxon and Celt represented this as, in part, a general difference, it is only natural that Anglo-Irish texts should have interrogated the prevailing political structures and issues through representations of romance, sexuality and gender. While not choosing an Irish setting, Le Fanu prefers to introduce the sexual corruption of Silas's unfortunate marriage to a lower-class Celt. Maud is placed at the centre of this conflictual issue: a great part of the plot revolves around her gradual discovery of her uncle's real nature. Herincomplete "relation to and ignorance of her heritage are part of her gendered unfitness for the task entrusted to her." (Howes 1992:180) Her father pities her, considering her to be too young. 
Nevertheless, he decides to perpetuate her ignorance about the sacrifice he is demanding of her. Maud's femininity renders her potentially inadequate to be an agent of traditional and genealogical continuity. She even seems to hold the same opinion as her father, commenting, after a number of years, that she was "but a hysterical girl". She views herself as possessing a "peculiar temperament" and her narrative constantly brings to the fore her weakness of character and the precarious state of her nerves. The adjective "nervous" is used so many times with reference to Maud that we are led to think she is hysterical. Marjorie Howes emphasises the fact that "the self-accusatory narrative of a self-confessed hysteric has precisely the structure of the Anglo-Irish Gothic." (Howes 1992:181) At the very beginning of the novel, Maud describes herself as a girl "of a little more than seventeen, looking, I believe, younger still; slight and rather tall, with a great deal of golden hair, dark-eyed, and with a countenance rather sensitive and melancholy" (Le Fanu 1864:5). To this first description of herself one may add a considerable number of subsequent descriptions, all of them contributing to the portrait of the Gothic heroine par excellence. Her sensitivity and melancholy are surely shaped in accordance with a thoroughly Gothic atmosphere, full of gloom and mystery: "great gusts were rattling at the windows, and a wailing and thundering among our tall trees and ivied chimneys - a very dark night, and a very cheerful fire blazing, a pleasant mixture of good round coal and spluttering dry wood, in a genuine old fireplace, in a somber old room." (Le Fanu 1864:5), "It is a long, narrow room, with two tall, slim windows at the far end, now draped in dark curtains. Dusky it was with but one candle" (Le Fanu 1864:9). The lexical sets of gloom, brooding atmosphere, fear and suspense appear with great frequency 
throughout the novel: very dark night, somber old room (p. 5), dark curtains, dusky (p. 9), "the scene grew more sad and lonely" (p. 36) and so on.

Marjorie Howes rightly considers that the Anglo-Irish Gothic's preoccupation with "unreliable, alienated, and empty centers of political power, and its focus on internal sexual corruption, find their corollary in Maud's emphasis on her helplessness, self-doubt, and emotional instability" (Howes 1992:181), both of these features invoking the contemporary definitions of femininity that linked it to nervous weakness and disease. The general impression is that this nervousness is somehow imposed by circumstances and especially by her gouvernante and, of course, by the atmosphere of her home: "I had more than an apprehension of her temper and fear of possibly abused authority. The large-featured, smirking phantom, saluting me so oddly in the moonlight, retained ever after its peculiar and unpleasant hold upon my nerves." (p. 21); "Madame was on an unusually large scale, a circumstance which made some of her traits more startling, and altogether rendered her in her strange way, more awful in the eyes of a nervous child, I may say, such as I was." (pp. 22-23); "She was by no means a pleasant gouvernante for a nervous girl of my years." (p. 23); “These strange occurrences helped, I think, just then to make me nervous, and prepared the way for the odd sort of ascendancy which, through my sense of the mysterious and supernatural, that repulsive Frenchwoman was gradually, and it seemed without effort, establishing over me." (p. 15); "Out went Madame's candle, and at the same moment, with a scream, I walked in the dark - still fancying myself in the library; and for an hour after I continued in a hysterical state." (p. 34); “'I'll stay here," I said, a little angry - for I was angry as well as nervous; and through my fear was that 
indignation at her extravagances which mimicked lunacy so unpleasantly, and were, I knew, designed to frighten me.” (p. 37). All the circumstances of her becoming angry seem to have been dictated by Madame de la Rougierre, who behaves so strangely: large-featured, smirking phantom, saluting me so oddly, peculiar and unpleasant hold upon my nerves, unusually large scale, her strange way, by no means a pleasant gouvernante, the odd sort of ascendancy, mimicked lunacy, strange occurrences. [+Odd] is the semantic trait that governs Madame de la Rougierre's behaviour. More than this, she appears no more woman than man, with her strange mixture of features that border upon monstrosity: "was that apparition which had impressed me so unpleasantly to take the command of me, to sit alone with me, and haunt me perpetually with her sinister looks and shrilly gabble?"(p. 21), "She eats like a wolf, she does, the great raw-boned hannimal ... you never saw such a sight. The great long nose and hollow cheeks of her, and oogh! Such a mouth! I felt a'most like little Red Riding-Hood" (Mary Quince's description), "She was tall, masculine, a little ghastly perhaps, and draped in purple silk, with a lace cap, and great bands of black hair, too thick and black, perhaps, to correspond quite naturally with her bleached and sallow skin, her hollow jaws, and the fine but grim wrinkles traced about her brows and eyelids" (p. 22). The characterization made by Mary Quince stresses her beast-like behaviour - she eats like a wolf - a comparison very common in Gothic, drawing attention to her abnormality. The colours that appear in the physical description of her - red, black and white (purple silk, black hair, bleached and sallow skin) - are in accordance with Mary Quince's perception of her as a nightmarish wolf-like Gothic presence. Mary Quince's exclamation "oogh! Such a mouth!" completes the portrait of this strange 
woman, adding, through its element of inter-textuality, further symbolic meanings of Madame de la Rougierre's presence in the house. With such a gouvernante and such gloomy surroundings it is natural that another semantic trait appearing in the descriptions of Maud's life should be [+Fear]: peculiar and unpleasant hold upon my nerves, designed to frighten me, with a scream, I walked in, made some of her traits more startling, [+Dread]: "I was frightened - I was wounded - burst into tears" (p. 149) Later in the novel, Maud will define herself as follows: "I think I had the mental attributes of courage; but then I was but a hysterical girl" (p. 108). Her definition must be read in connection with the background to her experiences: "Feverish and frightened I felt that night. It was sympathy, I fancy, with the weather. The sun had set stormily. Though the air was still, the sky looked wild and storm-swept. The crowding clouds, slanting in the attitude of flight, reflected their own sacred aspect upon my spirits. My grief darkened with a wild presaging of danger, and a sense of the supernatural fell upon me. It was the saddest and most woeful evening that had come since my beloved father's death.” (p. 121). The author uses inversion (feverish and frightened I felt that night), epithets (sun had set stormily, air was still, sky looked wild and storm-swept, crowding clouds, wild presaging of danger), metaphors (my grief darkened), and accumulation (the saddest and most woeful evening) in order to create the appropriate atmosphere for a Gothic heroine.

Although Uncle Silas has been described as a sexless novel, the most dangerous element in Maud's femininity is her sexual vulnerability. She views her femininity as a set of very probably dangerous sexual weaknesses and instabilities. Her assertion that if a woman is considered to be the weaker sex 
she should therefore act as such may be illustrative of the Anglo-Irish assimilationist ideology mentioned above. Maud's femininity is an element of internal corruption within her, a link with the barbarous, and she needs to undergo a process of observation and regulation. Milly is the best example of the unregulated and uneducated female character: her education is meant to make her less unreliable and less potentially disruptive. Uncle Silas defines Milly as a "very finished Miss Hoyden" and considers that her wildness of character is due to "that line of circumvallation which has, ever since [her] birth, intercepted all civilization on its way to Bartram" (p. 240). Maud is the element of civilisation that is meant to transform Milly, thus reinforcing the novel's sense of "female social and sexual identity as something that must be carefully constructed to avoid chaos" (Howes 1992:183).

Choosing a different angle of view, a realist one, the entire evolution of this Gothic heroine may be conceived as a struggle towards the ultimate solution: Maud's integration into civilized society. According to Claire Kahane, at the core of the Gothic novel lies hidden the "spectral presence of a deadundead mother, archaic and all-encompassing, a ghost signifying the problematics of femininity which the heroine must confront". (Kahane 1985: 336). The function of mother may be ascribed to Cousin Monica, a very warm and friendly presence who always gives Maud good advice. If we adopt this perspective, according to which the central mystery of the Gothic has to do with the problems of femininity and motherhood, Maud's leaving the decay represented by Knowl stands for her confrontation with the problematics of femininity. She leaves Knowl to confront her nervousness and her hysterical tendencies. Dangers, in the shape of Captain Oakely and Dudley Ruthyn, will 
inevitably appear. In the end Maud proves to be victorious and happily marries Lord Ilbury, subsequently bearing him a son. In this way she achieves a socially acceptable femininity and becomes integrated into civilized society. Through her advantageous marriage - a proof of her successful management of sexual threats - and through her role in civilizing Milly, she demonstrates her affiliation with the Anglo-Irish tradition represented by her father. On the other hand, her unstable cast of mind situates her on the border of barbarous instability, corruption and danger. As Marjorie Howes states, the novel's "preoccupation with Maud's femininity, its covert association of dangerous femininity with a specifically Irish corruption, its emphasis on the process of constructing a more stable female character through education and civilization, and its representation of sexual misalliance as the exemplary betrayal of tradition, all constitute its distinct Anglo-Irishness and subtly distinguish it from the English sensational thrillers of the period with which it competed." (p. 186)

In this context Madame de la Rougierre, through her French origins, is intended to represent a corrupting Continental influence, thus once more emphasizing the danger of assimilation. We witness a circular chain of "education": Maud is trying to civilize her barbaric cousin, while at the same time being the subject of education by the French governess, who is totally subservient to Silas Ruthyn. Duplicitous, grotesque, alcoholic, foreign and gender-ambivalent, Madame de la Rougierre is crucial to Maud's story and to the fate of her family: this is for Maud precisely the period of transition from girlhood, dominated by the father, to womanhood, dominated by the husband. As Elizabeth Bowen stresses when referring to the governess and the master in Uncle Silas, "As a woman, she can intrude on the girl at all points [...] While 
the uncle gains monstrousness by distance, the governess gains in monstrousness by closeness" (in Mangum 1997:215).

Madame de la Rougierre proves to be a character of nightmare rather than of education: she is a witch, a self-proclaimed "Madame le Morgue - Mrs Deadhouse". We never discover where Austin Ruthyn found her, yet the novel will later disclose that she is in league with Silas in his attempts to lay hands onAustin's will.

Obsessed with death, Madame frequently talks to Maud of ghosts and loves solitary graveyards. She threatens to introduce Maud to her friends "Monsieur Cadavre and Monsieur Squelette". Her threats alternate with pleasant words and promises and her gloom is punctuated by bursts of wild, probably drunken, hilarity. A veritable Gothic character, the gouvernante is an ogress figure, spreading horror around her: "I did not know well what to make of this woman, whom I feared with a vein of superstitious dread. I hated being alone with her after dusk in the school-room" (p. 26); "Her eyes were turned in the direction of the stairs, from which only she apprehended surprise. Her great mouth was open, and her eyes absolutely goggled with eagerness. She was devouring all that was passing there. I drew back into the shadow with a kind of disgust and horror. She was transformed into a great gaping reptile. I felt that I could have thrown something at her; but a kind of fear made me recede again towards my room." (p. 28) Maud's description assigns her gouvernante to the animal realm: this time she is like a reptile. Animality is rendered through the description of her mouth - her mouth was open - and of her eyes - absolutely goggled with eagerness. The verb "devouring" makes the scene perfect, inducing the idea of a fierce predatory animal. Another scene presents her as a representative of the 
animal kingdom once again - this time under the guise of a bird of prey: "She looked steadily in my face and very wickedly. I gazed at her as with dazzled eyes - I suppose as the feathered prey do at the owl that glares on them by night. I neither moved back nor forward, but stared at her quite helplessly." (p. 79) The expression of Madame's eyes dominates the scene. In fact this is the description of two pairs of eyes, one pair dominating the other, as shown by the antonymic pair "looked steadily $[. .$.$] and very wickedly" and "gazed at her with$ dazzled eyes". All the time Madame de la Rougierre dominates Maud by looking at her in such a way that the young heroine grows more and more frightened: "The large sinister face looked on me for a second with its latent sneer", "she said quietly, and eyeing me with a sinister smile" (p. 101), "Madame's evil smile, nevertheless, from time to time, would sail across my vision with a silent menace, and my spirits sank"(p. 102) [+Evil] (evil smile, silent menace, very wickedly and [+Monstrous animality] (sinister smile, devouring) are perhaps the most representative semantic traits that dominate the descriptions of Madame in the novel.

Le Fanu's style is "translucent, at once simple and subtle" (Bowen 1950:3) and is ideal for transitions of the alternation type: surprising events occur one after the other, proving Le Fanu's genius for the unexpected, both in mood and in event. Maud exemplifies such transitions: before coming to Bartram-Haugh she was extremely tense and full of apprehension. Once she has arrived there, Bartram-Haugh appears a site of freedom and delight when compared to Knowl. In her uncle's house Maud has company of her own age and enjoys the opposite of the somber and repressive atmosphere of her home. 
Every chapter brings something surprising, always filtered through Maud's feelings.

The absolute opposite of Madame de la Rougierre, Cousin Monica is portrayed as a friendly and likeable person. Her function is one of lightening the gloom Maud lives in. [+Gloom] and [+Dread] are semantic features present in the description of Maud's home. Maud herself notices a change: "and indeed, just then those black-panelled and pictured walls, and that quaint, misshapen room, seemed to have changed their stern and awful character for something wonderfully pleasanter to me" (p. 44) The young heroine begins to realize that there is more to life than she has previously seen or imagined.

Monica seems to assume the role of a mother figure. However, her advice is not very well supported by arguments - she knows things she does not want to tell her cousin. This technique of holding back information enhances the tension and suspense, especially since Maud's life depends on uncovering some horrid secret.

\section{Conclusion}

If we consider the entire range of feminine characters in the novel, Maud stands out as a character who exemplifies the position of women prior to the Married Women's Property Act (1872) and the movement towards emancipation. What distinguishes her is the fact that she is strong in spite of her appearance of intimidated heiress.

Through his disposition of characters, Le Fanu "shows himself, as a novelist, admirably professional, in the sense that few of his contemporaries were" (Bowen 1950:13). We may observe that not a single character is 
superfluous, not one fails to play his or her part in the plot. They are all very well integrated into the atmosphere, some of them creating a picturesque effect (due either to their physical appearance or to their language). Both through his characters and also through his skill in rendering a Gothic atmosphere and Gothic subject-matter in a way that was highly appreciated, Sheridan Le Fanu, in Uncle Silas, proved that he was in advance of his time, not behind it, as the work is "not the last, belated Gothic romance, but the first (or among the first) of the psychological thrillers" (Elizabeth Bowen), and since it possesses, as terror-writing, a voluptuousness that has never again been achieved.

\section{References:}

Bowen, Elizabeth. 1950. Collected Impressions. New York: Knopf

Howes, Marjorie. 1992. "Misalliance and Anglo-Irish Tradition in Le Fanu's Uncle Silas" in Nineteenth-Century Literature 47(2): 164-186

Kahane, Claire. 1985. "The Gothic Mirror" in The (M)other Tongue. Essays in Feminist Psychoanalytic Interpretation. Shirley Nelson Garner, Claire Kahane and Madelon Sprengnether (Eds.). Ithaca: Cornell Uni. Press.

Le Fanu, Joseph Sheridan. 1864. Uncle Silas. Wordsworth Editions Limited 2009. Great Britain: Clays Ltd

Mangum, Teresa. 1997. "Sheridan Le Fanu's Ungovernable Governesses” in Studies in the Novel 29(2): 214-237

Ogawa, Kimiyo. 2007. "Strangers within Our Gates" in Le Fanu's Uncle Silas" in Journal of Irish Studies 22: 16-23 
